\title{
黃土の化學的研究 (第一報補)
}

(昭和十八年十一月十九日受領)

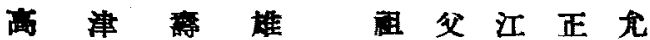

著者等は第一報に螋き其後に入手せる數種の黃土の內 ${ }^{23}$, 既に市販品として利用せられつっあると 稱せらる>山形縣產出のもの>外福島縣, 秋田縣, 樺太廳産出の黄土に就き化學分析を行ひたる結果 る報告する。

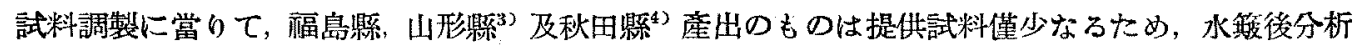
試料とすることが出來なかつた，樺太疆產出のものに就ては第一報同樣に取扱つた，分析方法並に 操作に就ては，第一報と全く同樣に行ひ，第 1 表に示す結果を得た.

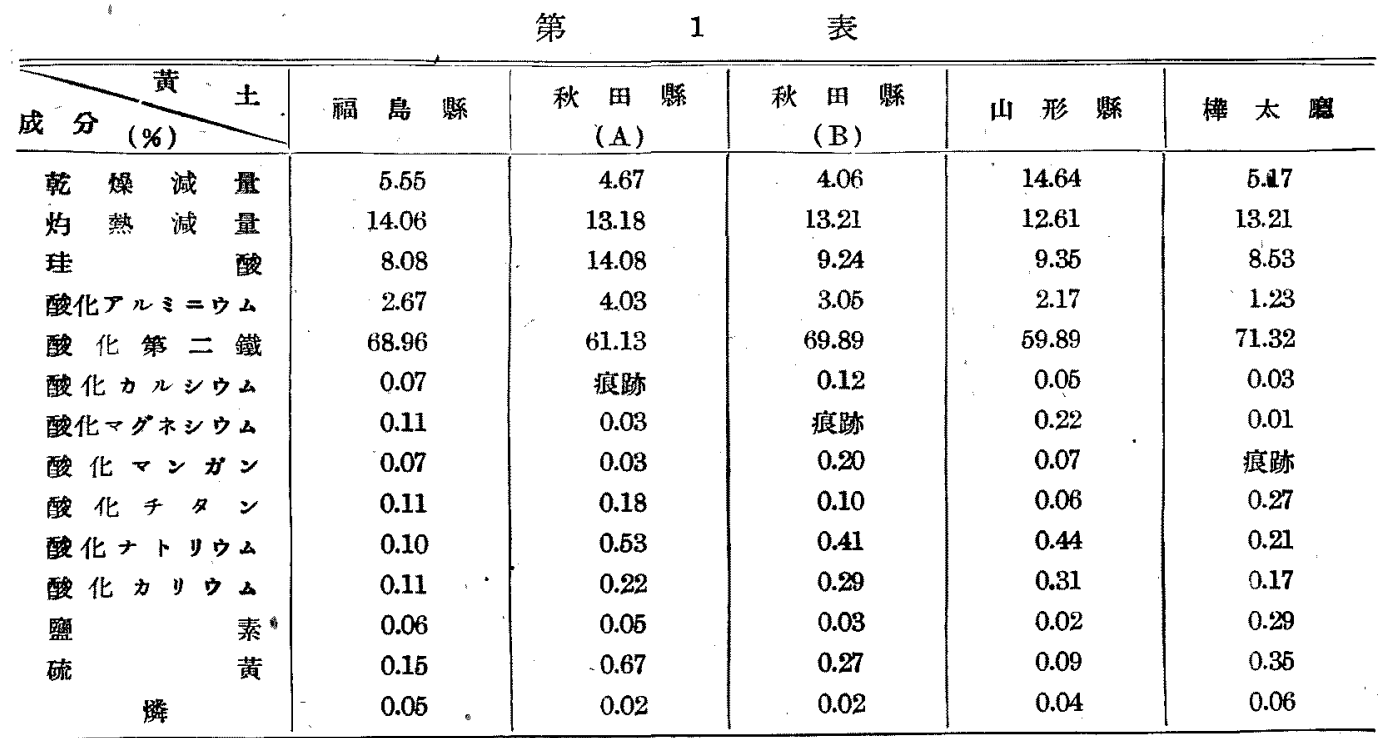

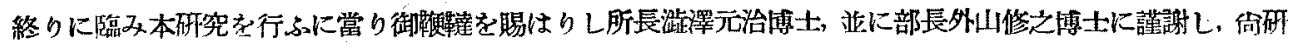
究費を仰ぎし愛知縣科學技術研究會に對し讙謝す

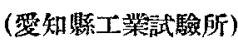

1) 制: 本誌, 64(昭和 18), 1197.

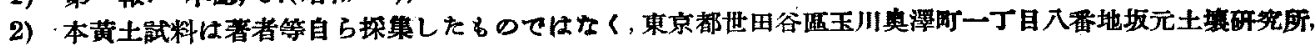
坂元㨁裁氏上り提供登付されたるのである

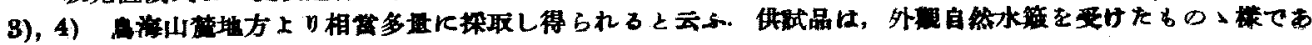
>te. 